\title{
Língua e efeitos de estranhamento: modos de (vi)ver o outro
}

\author{
Language and effects of strangeness: \\ ways of perceiving (and seeing) the other
}

Maria José R. F. Coracini*

Universidade Estadual de Campinas - Unicamp

RESUMO: Este texto se baseia na hipótese de que estamos sempre entre línguasculturas, mesmo quando falamos uma única língua. Tem por objetivo estudar relações interculturais e efeitos de estranhamento em relatos de brasileiros, que participaram desta pesquisa, sobre suas experiências em Portugal. Para este artigo, quatro relatos foram gravados e transcritos. A perspectiva teórica adotada se encontra no espaçoconflituoso e tenso - entre teorias do discurso, psicanálise lacaniana e desconstrução derrideana. Da análise é possível depreender que a suposta língua materna é também uma língua estrangeira, estranha em sua familiaridade, provocando sofrimento e gozo ao mesmo tempo. Refletir sobre isso é muito importante para compreender a si próprio e ao outro, língua e cultura, que constroem nossa subjetividade e, portanto, nossa identidade.

PALAVRAS-CHAVE: subjetividade, língua-cultura, língua materna, língua estrangeira, identidade, estranhamento

ABSTRACT: This paper is based upon the hypothesis that we are always between languages-cultures, even when we speak only one language. It aims at studying intercultural relations and the effects of strangeness, in narratives of some Brazilians, participating in this research, about their experiences in Portugal. For this paper, four narratives have been recorded and transcribed. The theoretical perspective is situated in the space - in conflict and tense - between discourse theories, Lacanian psychoanalysis and derridean deconstruction. From the analysis it is possible to notice that the supposed mother tongue is also a foreign language, strange in its familiarity, provoking suffering and enjoyment at the same time. Reflecting about this seems very important to understand oneself and the other, language and culture, responsible for our subjectivity and, therefore, our identity.

KEYWORDS: subjectivity, language-culture, mother tongue, foreign language, identity, strangeness

Parte de um projeto mais amplo, apoiado pelo CNPq, este texto parte da hipótese de que somos/estamos todos entre-línguas-culturas, mesmo

*mjcoracini@uol.com.br 
quando "falamos" apenas "uma" língua, no caso em questão, a língua portuguesa. Por vezes, esquecemo-nos de que a língua está inevitavelmente atrelada à cultura e, por isso, não raro deixamos de nos entender, brasileiros e portugueses, mesmo quando não sentimos nenhuma dificuldade em compreender o que outro diz, apesar das diferenças de sotaque, vocabulário e variantes sintáticas. Por outro lado, não raro somos todos acometidos por certo estranhamento, naquela que consideramos nossa língua materna, e, poderíamos afirmar, num mesmo país, entre estados, num mesmo estado, entre cidades, na mesma cidade. Entretanto, o Brasil, embora já tenha reconhecido estatutariamente línguas aborígenes como nacionais, continua se dizendo monolíngue, isto é, afirmando ser um país de língua portuguesa (língua oficial), como se esta fosse una, completa, a mesma em Portugal e no Brasil, a mesma em todos os cantos do Brasil.

Não estou defendendo uma língua brasileira, distinta da língua portuguesa (esse é um outro assunto), estou apenas trazendo à baila o discurso daqueles que, vivendo em Portugal, ainda que por um tempo determinado, sentem-se inseguros, perplexos diante das diferenças ou até mesmo diante das semelhanças antes não percebidas; de qualquer modo, trata-se de experiências que incidem na constituição identitária desses indivíduos.

Sabe-se que, nos últimos anos, inúmeros são os estudos realizados na Linguística sobre regionalismos, a respeito das diferenças entre as variantes existentes no Brasil (FAULTSTICH, 2009; RICARDO-BORTONI, 2004; BAGNO, 2005; LUFT, 1998, dentre muitos outros); outros ainda dentro ou fora do país, dedicaram-se ao estudo comparativo entre o português falado em Portugal e o português falado no Brasil, por exemplo, Gärtner (Ed.), 1997; JonAnd (s/d); Alves e Desmet (s/d). Entretanto, pouquíssimas são as pesquisas que se preocupam com as formaçôes identitárias na relação conflituosa de brasileiros vivendo em Portugal e de portugueses vivendo no Brasil.

Este texto pretende ser uma contribuição, ainda que incipiente e modesta, ao estudo das configuraçôes identitárias de brasileiros residindo em Portugal há pelo menos um ano. Trata-se de alunos e professores que se encontram em Lisboa por diferentes razóes, dentre as quais: fazer pósdoutorado, acompanhar o marido em seus estudos pós-doutorais, fazer mestrado ou doutorado, residir com a família que imigrou em busca de trabalho, de melhores condiçóes de vida. É preciso lembrar que as entrevistas feitas com cada um em particular não se constituíram de perguntas, mas de um incentivo verbal ao relato oral de suas experiências pessoais com relação às diferenças e às semelhanças, fios que se entrelaçam na tessitura, tecido, teia linguístico-cultural, que unem e desunem portugueses e brasileiros. 
Adotamos a perspectiva teórica que se encontra no espaço - conflituoso e tenso - entre teorias do discurso, psicanálise lacaniana e desconstrução derrideana - para refletir sobre a divisão incontornável do sujeito na sua relação com as línguas, ainda que se trate da língua dita materna.

\section{Alguns trajetos teóricos}

O pressuposto que sustenta a hipótese de que todos somos / estamos entre-línguas-culturas se ancora na premissa bastante conhecida de que toda língua se constitui de outras línguas; todo discurso, de outros discursos; de que não há língua pura, assim como não há nenhuma palavra que não seja atravessada por palavras de outro(s) ou mesmo por outra(s) palavra(s), proveniente(s) de outro(s) falar(es), de outra(s) lingua(gen)s, pelo já-dito, como diria Foucault (1971 [1996] $\left.{ }^{1}\right)$; afinal, o novo, o diferente não está no que é dito, mas na situação de enunciação que é sempre outra, sempre inédita, sempre diferente, sempre singular (FOUCAULT, 1996, p. 26). Trata-se, uma vez mais, de constatar a presença do mesmo e do diferente a cada ato enunciativo, a cada palavra proferida (DERRIDA, 1972a [1991, p. 7]).

Pensamento semelhante pode ser resgatado em Pêcheux e Fuchs (1975 [1997]), quando postulam os esquecimentos que têm servido de base para a Análise de Discurso, denominando esquecimento número um aquele que diz respeito à origem do dizer: o sujeito se esquece de que não é a fonte, a origem de seu dizer, que suas palavras são perpassadas por palavras (vozes) de outros, o que, de certa forma, desencadeia o esquecimento número dois, segundo o qual o enunciador acredita que faz uma escolha adequada de suas palavras, de modo que todos podem compreender o que diz da mesma maneira, esquecendo-se, portanto, de que cada qual compreende o que é dito conforme suas possibilidades, segundo condições de produção do sentido específicas (história de vida, outras leituras, etc.) que não podem ser controladas nem previstas. Se o enunciador, ou seja, nós, na posição de enunciadores, nos esquecemos de que todo dizer é atravessado pelo dizer do outro, então, vivemos na ilusão de que podemos ser originais, de que somos completamente diferentes, de que podemos atingir a completude e, por essa razão, sem cessar, até o fim de nossos dias...

\footnotetext{
${ }^{1}$ A primeira data refere-se à obra original; e a segunda, à obra consultada. As duas datas aparecem na primeira citação ou referência a uma obra; nas demais, assinalase apenas a data da obra consultada.
} 
É isso que nos move, é bem verdade, mas é isso também que nos faz adiar ad aeternum o suprimento ou o preenchimento (impossível, mas em cuja possibilidade acreditamos) da falta que nos constitui, do desejo que nos angustia, sem que possamos saber o porquê (já que não podemos realizá-lo), proveniente da castração que nos faz sujeitos cindidos, clivados, incompletos, sujeitos da linguagem, capazes de simbolizar. Mas, ao simbolizar, o sujeito deixa escapar, graças à porosidade da língua, fragmentos de lalangue (LACAN, 1975 [1985, cap. XI]; MILNER, 1978), do inconsciente, que emerge, sob a forma de lapsos, atos falhos, sonhos, deslizes metafóricos ou metonímicos... São esses momentos que acreditamos poder flagrar no e pelo discurso dos enunciadores, para melhor conhecermos a sua subjetividade - alegrias, sofrimentos, angústias, frustrações, por vezes desconhecidas deles próprios... -, além de pontos de identificação que nos permitam esboçar a sua identidade possível, mas ao mesmo tempo impossível, porquanto ela é, ao mesmo tempo, social e singular.

Dessa análise, é possível observar os efeitos de estranhamento de uns e de outros diante da língua-cultura supostamente una, que, no entanto, reserva surpresas tanto nas diferenças quanto nas semelhanças; perceber como um julga o outro, a partir de uma visão particular, que muito tem a ver com a realidade, as experiências, as razóes que levaram cada um a se ausentar de seu país de origem ou a emigrar, constitui um de nossos objetivos.

Há regiōes - diferentes para e em cada um, conforme o momento - em que a língua que nos constitui nos soa estranha: é como se dela não fizéssemos parte, como se ela estivesse fora de nós e nós fora dela. Palavras que, apesar de conhecidas, num dado momento, não fazem sentido; enunciados que, apesar de pronunciados inúmeras vezes, soam como se os ouvíssemos pela primeira vez ou, melhor ainda, como se fossem, ao mesmo tempo, estranhos e familiares. É a isso que Freud se refere quando lança mão do termo unheimlich (FREUD, 1919 [1976]). Cabe lembrar que, para que haja estranhamento deve haver algum ponto de identificação.

Outro pressuposto básico diz respeito ao monolinguismo tão desejado e tão buscado: apesar de nos defrontarmos com tantas situações de plurilinguismo, com tantas situações em que a primeira língua não é a língua portuguesa, mas a alemã, a italiana, a indígena, a polonesa etc., continuamos a nos referir ao Brasil como país de língua portuguesa, na crença ilusória na unidade linguística e cultural. ${ }^{2}$ Ora, como afirma Derrida (1996), não há língua que não se constitua

\footnotetext{
${ }^{2}$ Não podemos pensar em língua sem pensar em cultura e vice-versa, já que uma se constitui da outra.
} 
de outras línguas - basta considerar a história de invasões que precedem e sucedem a constituição de uma nação -, assim como não há sujeito que não seja perpassado, atravessado, constituído por traços de outros sujeitos, pela alteridade que o torna híbrido e complexo. Por essa razão, Authier-Revuz (1998) postula a nãocoincidência interlocutiva (os sentidos não são inteiramente partilhados), do discurso consigo mesmo, entre as palavras e as coisas, das palavras com elas mesmas.

A unidade linguística e subjetiva, sabemos por Derrida, constitui uma ilusão - ou uma promessa, cuja realização - impossível - é sempre adiada, diferida e, ao mesmo tempo, diferente (cf. différance em DERRIDA, 1972b, p.16-24), realização de totalidade que só existe no imaginário do sujeito (graças ao qual se vê ilusoriamente inteiro, completo), responsável pelo sentimento de identidade (lt.: idem: mesmo, uno).

Nossa pesquisa se pauta na memória que faz história-história social, história individual que é sempre história-ficção, porque se baseia em relatos orais de (re)memoração, que é, ao mesmo tempo, esquecimento e ficção de si (e do outro).

Observemos, então, alguns recortes.

\section{Algumas viagens...}

Imersos na língua-cultura do outro (português, em Lisboa), quatro participantes de nossa pesquisa, escolhidos para tecerem conosco a trama, a urdidura deste texto - viajantes desbravadores de mares e terras, em busca de um pai simbólico (terra, trabalho, nome) ${ }^{3}$ ou, simplesmente, em busca de conhecimentos a que acreditam não ter acesso e que fazem do outro alguém desejado, uma espécie de sujeito suposto saber, ${ }^{4}$ pois veem nele saberes que desconhecem -, apresentam reações ao mesmo tempo semelhantes e diferentes:

\footnotetext{
${ }^{3}$ A esse respeito, ler Calligaris (1991).

${ }^{4}$ Não queremos assimilar o sujeito suposto saber no contexto aqui abordado com o sujeito suposto saber na psicanálise, mas enfatizar uma certa semelhança de funcionamento subjetivo. No caso da psicanálise, o sujeito suposto saber é o analista: quem sabe sobre mim, sobre o meu inconsciente, não sou eu, mas o analista; esse saber que é suposto dá lugar à transferência. No caso dos brasileiros face ao outro - estrangeiro, seja português ou de outra nacionalidade -, há uma espécie de identificação imaginária com o outro, desconhecido, proveniente de uma fantasia que se constrói, a partir do que se ouve dizer ou do que se lê. Em contato com o outro, percebe-se, muito frequentemente, que o saber, previamente imputado ao outro, não existe ou não condiz com as expectativas.
} 
Jussara ${ }^{5}$ (há 6 anos em Lisboa) e Geraldo (há mais de três anos) se consideram imigrantes, no dever de se adaptar à sociedade que os acolhe, ao país hospedeiro e, como todo hóspede, de início - portas escancaradas - são bem-vindos (pois são trabalhadores em potencial), mas, depois, estranhos, começam a perturbar, a tirar a tranquilidade, a penetrar na intimidade, a invadir a língua e os costumes daqueles que se consideram na própria terra, na língua e cultura próprias, habitantes de propriedades inalienáveis... E aqueles que foram recebidos com carinho são, pouco a pouco, afastados, rejeitados, hostilizados, "hostipitalizados" (ao mesmo tempo hóspedes e hostis, amigos e inimigos) - termo extraído de Derrida (1997) -, úteis, porque, se empregados, ocupam lugares vagos no comércio (balconistas), em empresas de ônibus (motoristas), de limpeza (lixeiros, faxineiros), em residências (empregadas domésticas, babás), e, ao mesmo tempo, inúteis. Isso porque, se desempregados, perturbam o bemestar daqueles que encontraram a parte que lhes coube neste latifúndio; se empregados, em tempo de crise como o que estamos vivendo, ocupam o lugar de portugueses em situação de desemprego.

Além do mais, o hóspede que se delonga acaba alterando os costumes, desrespeitando as regras, as leis em vigor, contaminando a língua e a cultura... Tudo isso, como seria de esperar, gera, nos imigrantes, bem como nos hospedeiros, resistências e conflitos identitários, cujo sintoma se traduz numa espécie de mal-estar linguístico-cultural, como é possível perceber em alguns dos recortes analisados.

Para melhor organizar os resultados de pesquisa, dividimos os recortes mais representativos em dois grandes eixos situacionais que apontam para viagens com objetivos diferentes: a) ir para ficar: casos de imigração e b) de passagem: ir para não ficar.

\section{A) Ir para ficar: casos de imigração}

Jussara, estudante universitária na área da Educação, na Universidade de Lisboa, imigrante há seis anos, com aproximadamente 25 anos, casada com brasileiro, ambos nascidos no nordeste, viu-se na contingência de seguir seus pais que buscavam uma situação de vida melhor. Por isso, teve que trabalhar

\footnotetext{
${ }^{5}$ Os nomes dos participantes foram omitidos para que não haja qualquer possibilidade de reconhecimento; em seu lugar, foram colocados nomes fictícios: Jussara, Geraldo, Fabiana e Janete.
} 
e estudar, para tentar uma profissão que estivesse mais de acordo com seus desejos e exigisse dela menos sacrifícios. Na ocasião da entrevista, ela trabalhava como balconista numa loja de moda feminina, apenas em período parcial (do final da tarde até as $20 \mathrm{~h}$ ), por causa do curso universitário que exigia tempo integral. Seu marido era motorista de ônibus, mas já havia perdido emprego várias vezes consecutivas.

Observe-se no recorte (1) como Jussara se refere ao estranhamento causado pela escrita portuguesa:

$S 1$ - (...) / às vezes eu tenho que ler / umas quatro cinco vezes o mesmo parágrafo pra entender / porque a pontuação é diferente / não usam vírgula não usam ponto (...) É... / eles não / eu não consigo / eu tenho uma tremenda dificuldade de interpretação / eles têm um jeito de usar / parece que usa o pronome duas vezes / tipo me dão a mim / quer dizer tão dando a você duas vezes [risos] // E é uma coisa / sei lá pra minha cabeça é / depois escreve uma frase e num póe o ponto num põe uma exclamação não põe... aí você vai ler e ler, tem que ler tudo corrido [risos] // E aí pra entender / se perde e aí tem que voltar / eu tenho graças a Deus aqui na faculdade muitos textos são é: são traduzidos no nosso português aí eu sinto a diferença quando eu pego um texto no nosso português e um texto [inc.] eu sinto logo a diferença ${ }^{6}$ (Jussara)

Dificuldade de interpretar textos que, afinal, são escritos (supostamente) na mesma língua; estranhamento no que se refere à pontuação, ao uso dos pronomes... Língua do outro em oposição à "nossa" língua, ao "nosso português", ilusão de posse, de apropriação de uma língua (supostamente) una, pertencente aos brasileiros, como se falássemos e escrevêssemos todos da mesma maneira. Ficção de uma língua que se dá a compreender; homogênea, totalizante, essa língua ganha existência própria na diferença com a língua do outro; o mesmo e o diferente: a língua dele ou deles, em oposição à minha, à nossa língua.

\footnotetext{
${ }^{6}$ Legenda dos recortes: $S$ = seqüência, segmento; $S 1, S 2$ etc. = número do segmento apresentado no texto; [inc.] = incompreensível; [ ] = comentário da pesquisadora; I = pausa breve; $/ /$ = pausa longa; $(. .$.$) = palavras omitidas; ... (hesitação); : = vogal$ alongada; letras maiúsculas = ênfase na pronúncia; negrito $=$ trechos salientados pela autora.
} 
Geraldo também sentiu dificuldades provenientes das expectativas de uma língua una, cujas palavras - as "mesmas" na forma - deveriam, supostamente, ter o mesmo sentido:

S2 - Aí / vem outra questão / porque também senti imensas dificuldades não é / porque eu cheguei as paLAvras que nós pronunciamos no Brasil não são as mesmas / em sentidos, né / a gente / lá tem muitas palavras que funcionam de um jeito que eles empregam de outro então / eu fiquei / eu fiquei um pouco embaralhado / no INÍCIO / eu fiquei MUITO muito embaralhado / mas depois eu fui me habituando, as pessoas iam falando comigo e eu / eu na escola aprendia muito com as pessoas durante os intervalos, né / eles falavam comigo olha não aja dessa maneira / FALE assim, fale assado porque / é assim que ELES costumam falar então / eu fui pescando uma coisa aqui outra ali / e conseguia chegar a um consenso até / até eu estabilizar / (...) (Geraldo)

Geraldo, também estudante na área da Educação, espantou-se ao chegar a Lisboa, há mais de três anos: mesmas palavras com sentidos diferentes, o que o deixou um pouco embaralhado, muito embaralhado... Sentia-se interditado, para não dizer silenciado, na língua do outro que era, ao mesmo tempo, semelhante e diferente. Precisou do auxílio de um colega português - João (ver recorte abaixo) - para adaptar o "seu" português, de Belo Horizonte, ao português de Lisboa. "Enclaves" - termo usado em Portugal para dizer entraves, e - por que não? - em claves, em musicalidades outras, próprias de "outra" língua, que o seduzem de algum modo - achou "engraçado", cheio de graça, divertido; mas, ao mesmo tempo, "em traves", travado, podado, silenciado, no seu modo de ser e de dizer(-se). A oscilação entre línguavocabulário "completamente diferente" e "esses enclaves de linguagem [...] atrapalharam um pouco" (S3) e, no início do excerto, "tive imensas dificuldades" (adjetivo muito usado na linguagem coloquial, em Portugal) produz um efeito de contradição; afinal, se a língua é tão diferente assim, deveria gerar muita dificuldade para si e para o outro, muita "confusão", talvez por causa mesmo da "fusão entre as "línguas" - uma com a outra -, para constituir "uma" língua, imaginariamente a mesma, una, completa, estabilizada ou estabilizável, (como sugere Geraldo, em S2). Língua que é vocabulário, conjunto de palavras, a que é possível recorrer, como se recorre a um objeto qualquer. 
Mas é a diferença de mentalidade que mais espanta Geraldo:

S3 - me fazia muita confusão também o: / as palavras como / é: / ônibus e autocarro / não é / me fazia confusão essa palavra eu sempre que tava na sala de aula / ah porque o ônibus atrasou / o: ônibus, ônibus e os professores ônibus, ônibus [tentando imitar a maneira de falar dos professores] / é / o autocarro atrasou / ou seja essas / essas mini-palavras que eu tive que com o TEMPO me adaptando / recorrendo a elas / e o João do lado sempre falando não é assim / é assado / [risos] // e eu fui aprendendo com isso / ã: // o comboio também é muito engraçado / porque na minha cidade / em Belo Horizonte nós não chamamos de comboio nós chamamos de trem ou metrô / né/ que já (...) //É metro [com o $\underline{\text { e }}$ aberto] / já é completamente diferente / então esses enclaves de linguagem me atrapalharam um pouco quanto à adaptação de país // (...) completamente diferente / né / principalmente a mentalidade dos jovens / eu não sei / quanto ao namoro / né / especificamente quanto ao namoro / é: muito estranho você sair de um país em que as pessoas é: / em que as pessoas que querem namorar umas às outras vão à casa e pedem os pais e perguntam, olha, eu posso namorar seu filho? / aqui já não existe tanto isso aqui os jovens já são mais independentes / sabe / não existe muito esse esse contato de que / olha vou falar com o seu pai pra ver se eu posso namorar ou / com você / ou // na minha cidade há essa / essa cultura BEM impregnada mesmo / bem impregnada (...) (...) tinha mais alguma coisa que me incomodava e que e que eu fiquei assustado logo no início / mas depois passou porque até então a gente tem que adaptar / forçosamente ou não / nós temos que adaptar porque vivemos aqui / então AQUI nós temos que adaptar (Geraldo).

Observe-se, em primeiro lugar, a generalização, característica do discurso sobre o outro, pertencente a um grupo social ou a uma nação. Assim como Jussara generaliza ao afirmar que todos os portugueses são "estúpidos / ignorantes mesmo" e, ao contrário, todos os brasileiros são naturalmente simpáticos, Geraldo faz o mesmo ao falar sobre a mentalidade dos jovens tanto no Brasil quanto em Portugal, no que diz respeito "ao namoro": para ele, no Brasil, todos ("as pessoas") pedem aos pais para namorar, cultura que estaria "BEM impregnada mesmo, bem impregnada", no país e que se opõe ao modo como os jovens agem em Portugal ("aqui já não existe tanto isso aqui os 
jovens já são mais independentes") e tudo isso o "assustou um pouco". Essa tendência à generalização - porque, na verdade, trata-se de atitudes específicas de um estado, de uma cidade ou, mesmo, de uma família - carrega o efeito de sentido de que ninguém age ou pensa de outra forma, homogeneizando modos de ser que são sempre múltiplos e heterogêneos, sobretudo nos dias de hoje em que não há mais padrões culturais fixos e estáveis.

Em segundo lugar, as hesitações, as repetições e, sobretudo, a oscilação entre pouco e muito, referindo-se ao mesmo aspecto (é completamente diferente...; atrapalharam um pouco...; completamente diferente...) apontam para a reflexão que se dá no momento de enunciação, mas também para a dificuldade que o sujeito tem de mensurar ou qualificar as diferenças linguísticas, que são sempre culturais, entre Portugal e Brasil, que ele generaliza a partir de seus próprios parâmetros, já que essas diferenças partem de sua experiência: diferenças entre ele mesmo, que se vê na posição de representante brasileiro, e o outro, considerado por ele representante do país hospedeiro.

Adaptar-se é a lei tácita, subentendida, que rege a permanência do imigrante, que se impõe e impóe uma nova ordem do discurso àquele que sai de seu país; afinal, como afirma Jussara, "nós estamos no país deles"; aqui "eles têm sempre a última palavra" e, como diz Geraldo, "até então a gente tem que adaptar / forçosamente ou não / nós temos que adaptar porque vivemos aqui / então AQUI nós temos que adaptar" (final de S3). A repetição (três vezes) da modalidade deôntica marcada pela locução "tem(os) que" recaindo sobre outro verbo, no caso, adaptar(-se), aponta para a obrigação tacitamente imposta pelo outro, que aparece como um locativo (aqui), e que precisa ser aceita e respeitada, se quiser permanecer no país alheio. Submissão ao poder daquele que hospeda, que, ao mesmo tempo, acolhe (lt.: hospes) e hostiliza (lt.: hostes), dois radicais latinos com a mesma raiz: hostes deu em português hotel (fr.: hôtel), hotelaria (que hospeda) e hospes, de que resultou hóspede, hospitalidade, hospital, hospício, que constituem palavras com sentido semelhante; entretanto, de hostes derivam palavras como hostil , hostilidade, de modo que é possível criar um termo, como Derrida o faz, unindo os dois radicais: "hostipitalidade", em que sentidos opostos - hostilidade e hospitalidade - se imbricam (DERRIDA, 1997, p. 45). Eles e nós, ele e eu o hospedeiro e o hóspede, um diante do outro, um constituindo o outro, um modificando o outro, um incomodando o outro.

Mas, Jussara é mais sensível ao sofrimento da imigração: ela não consegue perdoar as experiências sofridas por que passou; por isso, conclui sua 
entrevista-relato afirmando que seu maior desejo é voltar para o Brasil; justifica tal atitude dizendo que os portugueses são "um povo muito estressado / e ESTÚPIDO por natureza / eles são estúpidos ignorantes mesmo / isso não é nem de propósito (...) / do jeito que a gente é simpático eles são estúpidos". Observe-se que o outro, aquele que, por alguma razão, faz alguém sofrer, ainda que sem querer (é natural), é "estúpido", "ignorante" por oposição a imigrante ("a gente") que é simpático por natureza... Jussara não fez o luto de sua línguacultura, não deixou que o que parecia (ou deveria estar) morto, fosse enterrado: continuou a viver no e pelo morto, na esperança de mantê-lo (e manter-se) vivo(a): viver no morto é uma forma ilusória de resguardar a sua identidade, sem se dar conta de que tudo muda, de que nada permanece como era: nem o lugar que deixou há cinco anos nem ela que trabalha, estuda e está casada em Lisboa. ${ }^{7}$

Geraldo, por sua vez, nascido no interior de Minas Gerais, imigrante como seus pais, que foram ao encontro de melhores condiçóes de vida, estava, na ocasião da entrevista, estudando na Faculdade de Educação da Universidade de Lisboa. Já havia trabalhado em postos de gasolina durante a noite para ganhar algum dinheiro, mas, no momento, se dedicava aos estudos e via, como algo muito remoto, o seu retorno ao Brasil, apesar das dificuldades iniciais de adaptação, em que se trancava no quarto para não sair de casa. Apesar disso, reconhece as mudanças que a experiência do outro, o sofrimento do luto, manifestado, sobretudo nos três primeiros meses, em lágrimas, produziu efeitos na constituição de sua identidade que ele percebe em mudança, em transformação:

S4 - Eu tento fazer os dois lados vamos dizer assim [risos] / eu tento fazer o lado brasileiro quando tô com os meus amigos / com / com as minorias que há aqui dentro do país quando eu tô com eles eu procuro ser BEM brasileiro / pra lembrar um pouco daquilo que eu / que eu sou ou / ou o que eu era / não é / vamos dizer assim / porque hoje eu continuo sendo brasileiro / mas como eu disse há valores que foram perdendo / há / há certas coisas que foram sendo dissipadas com o tempo / com o tempo que eu tô aqui / então eu procuro COM ELES estar assim / firmar mesmo a minha cultura (...) e quando tô com os portugueses já TENTO de alguma forma / não é / que eu interaja com eles de uma

\footnotetext{
${ }^{7}$ Seu marido é brasileiro, o que reforça sua atitude de não enterrar o morto, de nele e por ele viver.
} 
forma diferente / mas / é: eles quase te puxam pra isso / não é / porque há sempre / eu não sei se brincadeiras que pra / pra os meus amigos brasileiros / é: são engraçadas / são importantes pra eles já podem não ser (...) Né / então eu tento sempre que / é: esse fator de equilibração ou seja / eu sou uma coisa com os brasileiros que com eles eu não sou PORQUE eu acho que eles podem não gostar (...) (Geraldo).

Geraldo fala de si, como se estivesse consciente de uma - ilusória dupla identidade ("que eu sou ou / ou o que eu era"), que o faz agir de maneira diferente, se estiver com brasileiros ou com portugueses: busca se equilibrar na corda bamba das culturas, fazendo uso do "jogo de cintura", uma das características culturais de que os brasileiros em geral se gabam, procurando ser brasileiro com os amigos que lá residem, na crença de que, assim, poderão resguardar a sua identidade, e ser português, para agradar aos portugueses. Como numa balança, Geraldo procura penetrar na cultura portuguesa para agradar aos que o acolheram e não abandonar aquela que ele acredita ser a "sua" cultura, ou, ao menos ter sido, porque percebe a mudança (hoje eu continuo sendo brasileiro / mas como eu disse há valores que foram perdendo / há / há certas coisas que foram sendo dissipadas com o tempo). De um lado, esforça-se para manter o morto vivo, para não esquecer quem era, suas origens, para "ser BEM brasileiro"; por outro, tenta encontrar um espaço dentro de si para o novo pai, a nova lei, o novo modo de ser e de ver o mundo; mas, como acredita não ter feito o luto de sua pátria (palavra derivada de pater) esforça-se por ser brasileiro e português, sem se dar conta de que, ao generalizar os comportamentos, atribui a cada povo uma identidade única, inteira, completa, e a si, a capacidade de uma ilusória dupla identidade: ora é um, ora é outro.

A bem da verdade, Geraldo não é mais brasileiro, ou melhor, mineiro, nem português, ou melhor, lisboeta, mas encontra-se em trânsito, entre línguas-culturas, entre múltiplos estranhamentos, entre o que era e o que é. Aliás, a esse respeito, observe-se, mais uma vez, a oscilação marcada pelo verbo "ser" no presente e no passado: “... lembrar um pouco daquilo que eu / que eu sou ou / ou o que eu era"; o verbo "lembrar" remete necessariamente ao esquecimento: só se lembra do que esqueceu, ou só se lembra porque esqueceu e só se esqueceu porque se transformou, porque não é mais quem era.

A insistência, em S3, mas também em S4, em explicar cada afirmação sua aponta para o efeito de sentido do incômodo, que sente, seja por ter se adaptado ao outro, seja por querer manter-se como era, seja, ainda, por sentir- 
se na (con)fusão identitária: identidades fundidas, híbridas, que se chocam pela grande diferença, como explicita Geraldo, ao responder à pergunta-Como você se sente? -, feita pelo pesquisador a partir do próprio relato (ver fim de S4):

S5 - Conflituoso / completamente conflituoso / eu me sinto / há dias que nem eu me reconheço / porque é um conflito interno terrível / por quê? / porque eu tento ser / como eu disse / O brasileiro mas ao mesmo tempo tempo tento tento / TENTO ser O português / mentalidade mentalidade / é: / portuguesa que não batem com a brasileira e vira / e vira aquele CHOQUE / né / e eu penso assim / mas hoje / porque hoje se você for me pedir pra definir / pra EU me definir quanto pessoa / eu acho que eu não vou saber te dar uma definição / porque eu sou uma mistura / eu me misturei é uma / é uma mistura de tudo / é: é o brasileiro que quer / às vezes / é: / sobressair sobre o português e às vezes é o português querendo sair / sobressair sobre o brasileiro / e fica nesse dualismo e nessa conflituosidade / eu não entendo sinceramente [risos] (Geraldo)

O conflito se manifesta, na materialidade linguística, pela ênfase em alguns termos (grafados em letras maiúsculas), pelo gaguejo, marcado pela repetição de palavras (tempo tempo tento tento TENTO... mentalidade mentalidade... e vira e vira...), pela hesitação (é: portuguesa), pela ênfase em outros termos (grafados em letras maiúsculas), como "O brasileiro... TENTO... O português... CHOQUE”. Tal conflito - subjetivo, pessoal (ver primeira pessoa do singular, no recorte apresentado) - encontra sentido na tentativa de, ao mesmo tempo, continuar a ser o brasileiro, que não quer apagar em si e o português, que precisa ser, para poder viver bem e encontrar um lugar numa sociedade da qual não fazia parte até pouco tempo -, conflito que provém do choque de culturas (que ele denomina "mentalidade"), mas que é um conflito de identidade, marcado pela impossibilidade de se definir ("não vou saber te dar uma definição").

Se, no excerto anterior, Geraldo mantém a dicotomia, a separação entre as duas identidades, em S5, ele se dá conta da mistura (mistura de tudo) e da dualidade que o constitui (éo brasileiro que quer / às vezes / é: / sobressair sobre o português e às vezes é o português querendo sair/sobressair sobre o brasileiro), mas como saber quando um se sobressai ao outro, quando um "sai" e o outro fica, como aponta o ato falho "sair", logo corrigido por "sobressair"? Há momentos em que fica mais ou menos clara e consciente tal sobressalência (enfatizada pela retomada da preposição "sobre ("...sobressai sobre...), mas há, 
com certeza, outros, em que, sem se dar conta, é o português falado em Minas Gerais e, por consequência, a cultura mineira que se manifesta em meio a expressões e modos de pensar e de ser tomados do hospedeiro, como modo de garantir uma vida digna, em terras alheias. Assim, a "conflituosidade" (cf. S5) provém do choque cultural que se e(in)screve na linguagem, colaborando para a construção de uma identidade híbrida, heterogênea, complexa, incompreensível até, como afirma Geraldo, que se sente, às vezes, mais brasileiro, outras vezes, mais português, sem nunca deixar de ser um e outro, con-fusão que se materializa na e pela linguagem, através da comparação "mais...(do que...)".

\section{B) De passagem: ir para não ficar}

Se, para uns, é difícil ser o outro, o estranho, constituir-se de traços daquele que hospeda, recebe, acolhe e, ao mesmo tempo, exige que ele entre na ordem do discurso vigente, precisando, para isso, abdicar de sua línguacultura, para outros, que não vêm para ficar, simples transeuntes, passantes que permanecem um ou dois anos, para estudos, é "fácil ser a outra" (cf. S6) - a amante, aquela que chega de improviso, sem ser esperada, aquela que é diferente, que (se) desestabiliza, mas por pouco tempo. É o caso de Fabiana e Janete, que permaneceram um ano em Lisboa.

Fabiana, mineira de procedência, com seus 40 anos, foi para Lisboa como acompanhante do marido que, na ocasião da entrevista, se encontrava no final de seu pós-doutorado na área de Exatas, na Universidade de Lisboa. Janete, por sua vez, com seus 55 anos, nascida e radicada em Fortaleza, estava na metade de seu segundo pós-doutorado na área da educação, sempre na Universidade de Lisboa, muito feliz com o desenrolar de sua pesquisa e com a relação que pode estabelecer com seu supervisor. Essa ênfase no êxito das relaçôes se explicava por ter tido uma experiência anterior traumatizante, numa universidade da Alemanha, por ocasião de seu doutorado, como ela menciona em seu relato (ver mais adiante).

Passemos ao relato de Fabiana. Seu dizer aponta para o imaginário, para as expectativas, por vezes frustradas, que, por isso mesmo, são causa de estranhamento: a língua é a mesma e não é a mesma ou "não é tão a mesma", já que sente dificuldades de compreender a linguagem coloquial, as gírias, e com elas, a cultura, "as pessoas": 
S6 - Com certeza houve muita diferença / eu acho fácil de ser / a OUTRA né? / ser o diferente / por mais que Portugal tenha / nós temos / várias ligações com Portugal / mas é é é diferente / estar num OUTRO país / é: a língua / a mesma língua mas não É tão a MESMA língua assim / eu até hoje tenho dificuldade de entender ALGUMAS pessoas / aí vai depender da dicção da forma / como diz / e claro / algumas gírias que não são / como as nossas (...) // então essa essa questão da língua teve SIM um impacto / mais do que eu imaginava / em relação à cultura / primeiro foi muito interessante / é / conhecer ver as nossas heranças (...) principalmente porque eu sou de Minas (...) // então as nossas cidades históricas são comPLEtamente portuguesas / assim quando vi a arquitetura portuguesa / é: o estilo / português / de / de construir as cidades / então tive essa ligação muito forte com as cidades históricas mineiras / assim era muito forte isso // a questão da culinária foi outra que (...)// você fala poxa então é daqui MESMO que a gente tem as heranças (...) // E de perceber essa ligação que é muito mais forte do que a gente imaginava (Fabiana).

A língua, a arquitetura, a culinária portuguesas apontam para identificações que se manifestam por sensações de estranhamento: o familiar parece estranho e o estranho parece familiar. Fabiana percebe que o Brasil é mais português do que imaginam os brasileiros - principalmente os de Minas Gerais, estado que aloca cidades históricas, cuja arquitetura e culinária foram herdadas de Portugal $\mathrm{e}$, por isso, se assemelham às portuguesas -, ou melhor, do que ela imaginava, pois é dela que partem as observações, é dela e nela que se ex-põem as semelhanças e as diferenças. Estas se encontram, paradoxalmente, segundo Fabiana, na língua, que imagina(va) semelhante, mas que, não raro, se torna(va) incompreensível, diferente e semelhante ao mesmo tempo, a ponto de, em várias situaçōes, ter a sensação de que está(va) "ouvindo REALMENTE uma OUTRA língua / que no final do dia você fica cansada / com a cabeça doendo", como afirma Fabiana mais adiante, tal como uma língua-cultura estrangeira que exige muito esforço, muita atenção. Afinal, trata-se mesmo de uma línguacultura estrangeira $-\mathrm{e}(\mathrm{x})$ strangeira, prefixo $(\mathrm{es}=\mathrm{ex})$ - de fora, que vem de fora, de fora de si, que ex-siste fora-, apesar do reconhecimento inquestionável de semelhanças, umas conhecidas e outras desconhecidas (como o arroz doce, que Fabiana tinha certeza que fosse tipicamente mineiro, mas que, na verdade, é uma herança de Portugal). É por isso que o estrangeiro é aquele que coloca a primeira questão, que me coloca em questão, que coloca em questão a própria 
autoridade (autor-idade) e, portanto, o seu poder, daquele que se encontra, enquanto nativo, em posição hegemônica.

Ainda, em S6, vale observar, no discurso, a insistência em marcar, de um lado, as diferenças e as semelhanças, reduzindo o espaço entre elas: éX, mas não é tão X assim; e, por outro, radicalizar as semelhanças: "nossas cidades históricas são comPLEtamente portuguesas... então é daqui MESMO...”, apagando o diferente que, inevitavelmente, persiste, ainda que a arquitetura e a culinária encontradas em Portugal provoquem uma forte identificação em quem conhece Minas Gerais e suas cidades históricas, como é o caso de Fabiana.

E ela vai mais além, na detecção da diferença linguística:

S7 - (...) quando eu fui a Barcelona num congresso / a gente depois saiu com um catalão né? / um espanhol catalão / com a sua mulher também espanhola catalã e uma portuguesa // EU compreendia MUITO mais fácil os dois espanhóis / do que A PORTUGUESA (...) Eu fiquei assim / mas não é POSSÍVEL / alguém da minha língua / ela falava tão rápido e tão / é rápido e pra dentro assim / tem um / assim não sei se você já percebeu eles tem um jeito mais / como que eu digo assim / mais pra dentro / num sei / eu sei que essa portuguesa eu tinha que fazer um esforço que eu não fazia com os espanhóis / eu entendia CLARAMENTE os espanhóis / claro que eles também / faziam talvez uma fala mais devagar / enfim / mas eu consegui travar uma conversa com os espanhóis que eu não consegui com o português / que coisa estranha [risos] (Fabiana).

Fabiana apresenta uma situação de confronto entre a língua portuguesa, supostamente una e a língua espanhola (catalão), supostamente uma língua estrangeira. Por meio de comparações entre as duas, com relação à compreensão oral, conclui que a primeira lhe soou muito mais estrangeira do que a segunda, porque não conseguia compreender uma colega portuguesa, contrariamente à clara compreensão do catalão: remete ao sotaque, à rapidez da fala, à abertura de vogais, no português de Portugal, que, por sua vez, é comparado ao "seu" português (falado no Brasil): comparação dentro de outra comparação. Mais um estranhamento que Fabiana explicita no final do recorte (“...) que coisa estranha"): o que devia ser familiar soa-lhe estrangeiro e o que devia ser estrangeiro soa-lhe familiar! Embora as explicações tentem amenizar as disparidades, a ênfase em algumas palavras (grafadas em maiúsculas) apontam para diferenças flagrantes para ela. Observe-se ainda o uso da primeira pessoa do singular, marca explícita de relato de experiências e impressões pessoais; a propósito, o relato 
não oculta o interlocutor - no caso, a pesquisadora -, a quem Fabiana se dirige, buscando conivência: "(...) não sei se você já percebeu...” (S7).

Vejamos, então: se Jussara não faz o luto da própria língua-cultura, mitificando-a e vigiando para que ela(s) não desapareça $(m)$ - ela, a línguacultura? Ela, Jussara? Ou ambas? -, se Geraldo busca se adaptar e reconhece o bem que a experiência de viver - ver e ver-se - em Portugal causou na formação de sua identidade, se Fabiana, embora de passagem, aponta para identificações, que se manifestam por muitos estranhamentos, o dizer de Janete (em S8 e S9) produz um efeito de deslumbramento, de paixão pelo outro (no caso, Portugal, os portugueses, a língua, a cidade, os aspectos culturais), paixão essa que, segundo Barthes (1977 [1990], ainda se encontra no primeiro estágio, fase em que não se veem os defeitos do outro, em que tudo nele é maravilhoso: Janete "sente-se em casa", "MUITO bem", "em paz" consigo mesma e com a cidade, "ADORA as pessoas", acha "o português belíssimo":

S8 - é eu me sinto muito bem eu me sinto / acho que eu me sinto em casa/ às vezes eu esqueço que eu não sou daqui que não nasci aqui / e: talvez por experiência anterior que eu tive na Alemanha eu fiz meu doutoramento e meu pós-doutoramento na Alemanha passei quatro anos e meio no norte da Alemanha e LÁ eu vivi um choque cultural brutal / né? (...) desde que cheguei que eu me sinto MUITO bem / eu me tô em paz comigo em paz com a cidade ADORO as pessoas acho o português de Portugal belíssimo (...) (Janete).

A ênfase com que Janete expõe suas sensações, sempre na primeira pessoa do singular e por meio do verbo opinativo ("acho"), repetido duas vezes, aponta para um bem-estar raramente encontrado naqueles que vivem, por um tempo, fora de seu país de origem. O esquecimento de suas origens brasileiras (nordestinas) reforça essa conclusão, que ela busca justificar por outra experiência bem diferente. $\mathrm{O}$ recorte acima e sua afirmação, ainda durante essa entrevista-relato, de que não sente saudades do Brasil nem da cidade que deixou para trás por um tempo (Fortaleza), permite afirmar que Janete fez o luto do seu idioma e da sua cultura, para se apropriar do idioma e da cultura do outro, que, de algum modo, constitui sua subjetividade de pertencente a um país colonizado por portugueses; talvez seja essa a razão que justifica, por vezes, seu esquecimento de que não nasceu em Lisboa (cf. S8). Viria daí seu deslumbramento, sua admiração, sua paixão? Seria o efeito de um desejo que ficou lá na Europa, como sugere Calligaris (1991), de onde alguns parentes emigraram no passado, 
deixando marcas indeléveis em sua subjetividade? No dizer de Janete, o fascínio, marcado em sua fala por certos exageros (ADORO, belíssimo, MUITO bem...), que aponta para identificações, decorre de outra experiência, na Alemanha, onde se sentiu realmente estrangeira, onde vivenciou "um choque cultural brutal". Ou todas essas razões se imbricam, se cruzam, se complementam e apontam para uma forte paixão, produzindo esse efeito de bem-estar e deslumbramento? Janete não passará pelas outras fases do discurso amoroso e, portanto, não (vi)verá a transformação de seus sentimentos, com relação a Portugal: ela está aí de passagem.

Janete prossegue o seu discurso amoroso:

S9 - TANTO que pela primeira vez na VIda eu sinto é: uma saudade antecipada eu nunca senti isso na minha vida de sofrer por antecipação quando eu me lembro que em abril eu vou embora / e e eu vou morrer de saudade daqui eu JÁ tô com saudade daqui / eu tenho saudade das ruas eu tenho saudade do modo de falar eu tenho sau saudade do Fábio eu tenho saudade do Bairro Alto eu tenho saudade das pastelarias $^{8}$ eu tenho saudade aTÉ da universidade / desse convívio com meu professor com os alunos do mestrado eu fui MUIto bem recebida parece assim uma forma de compensação por tudo o que eu passei / de ruim na Alemanha [...] (Janete)

Sem tempo para atravessar a segunda etapa da paixão, momento em que o deslumbramento cederia lugar à decepção diante das falhas, da falta constitutiva do outro, do incômodo das diferenças nem sempre suportáveis, como afirma Barthes (1990), Janete declara sua paixão: chega a sentir saudades antecipadas de tudo e de todos ("vai morrer de saudades"). Confessa seus sentimentos: essa é a primeira vez em que não quer voltar para a sua cidade, para o seu país, em que sofre "por antecipação": sofrimento que é gozo e gozo que é sofrimento... É tão estranho tudo isso que ela precisa justificar para si e para a pesquisadora: tudo isso "parece assim uma forma de compensação por tudo o que pass[ou] de ruim na Alemanha". O modo como marca positivamente a sua experiência em Portugal - saudade das ruas, das pessoas, dos amigos, até da universidade (como se não fosse normal sentir saudades da universidade) - aponta para a sua experiência oposta: na Alemanha, foi mal recebida, por

${ }^{8}$ Em Portugal, pastelaria corresponde a confeitaria; pastel é um doce. 
todos, não sente saudades de nada... Mas, está marcada por essa vivência tanto quanto por esta: uma e outra se encontram presentes, fazendo de Janete alguém diferente, em constante mutação, ainda que disso não se dê conta.

Antes de alinhavarmos nossa rede, para lançá-la ao mar, gostaríamos de circular os risos que marcam quase todas as entrevistas-relatos, risos de quem relata e risos simultâneos de quem ouve. Retornemos aos recortes aqui trazidos. Em S1, os risos (assinalados duas vezes pela pesquisadora) sucedem ao comentário de Jussara sobre a dificuldade de interpretação provocada pelo uso dos pronomes, na escrita, e pela pontuação, por parte dos portugueses, o que Jussara enuncia de forma intempestiva. Em S3, no momento em que Geraldo se refere à presença constante, em sala de aula, de um colega (João) para lhe dizer, o tempo todo, como devia falar e agir - situação esdrúxula, por estar ele no país de origem da língua portuguesa. Em S4, logo no início do recorte, após a confissão de Geraldo de que tenta fazer os dois lados: o brasileiro e o português, colocando em ação o famoso "jogo de cintura" atribuído à cultura brasileira, numa situação em que isso parece impossível. Em S5, no final, quando Geraldo diz não compreender o conflito em que vive: ora é o brasileiro que sobressai, ora é o português... Em S7, quando Fabiana expressa seu estranhamento diante da impossibilidade de compreender o português falado por uma colega portuguesa.

Em todos os casos assinalados, trata-se de uma reação espontânea a situaçôes de estranhamento, uma espécie de riso histérico, diante das próprias dificuldades: rir de si mesmo, dos próprios sofrimentos, como uma maneira de sobreviver, de lidar com sintomas e dores, de resistir e se defender do sofrimento, dos incômodos das situações perturbadoras, inesperadas. O riso, em seu "caráter rebelde e transgressivo" (CAMPOS; ARAGÃO, 2009, p. 3), propicia um momento de descontração, partilhado pelo entrevistado e pela pesquisadora, ao mesmo tempo em que aponta para a estranheza da situação relatada, inesperada e surpreendente, permitindo ao sujeito "distanciar-se de sua dor" (Op. cit., p. 5), (re)vivida pelo e no relato, ao mesmo tempo em que abre caminho para a criação de novos sentidos.

\section{Algumas (in)conclusões}

A título de conclusão, inconclusiva, diga-se de passagem, sobretudo porque se trata de fragmentos de análise, que não se pretende nem pode ser quantitativa, exaustiva ou generalizante, pois cada um dos participantes (res)sente à sua maneira cada experiência vivenciada, cada um vive e se vê e vê 
o outro de forma singular, ainda que em situações aparentemente semelhantes, e com dizeres que carregam o já-dito, foram bordados - nas bordas e a bordo - vários pontos, com fios que transbordam dos relatos-tecidos-textos. Desses fios três se unem e se imbricam em ponto de arremate, embora este possa ser desfeito e refeito.

Primeiro fio. É nos e pelos efeitos de estranhamento que apontam sempre para processos de identificação - ora imaginária, ora simbólica, ora fantasística -, que conseguimos nos dizer, nos singularizar e, ao mesmo tempo, nos compreender e compreender o outro que nos constitui e que, frequentemente, nos incomoda como um estranho que perturba a tranquilidade (ilusória) do "estar em sua própria casa". Se estranhamos o outro ou nos estranhamos no outro, somos também estranhos para ele e compreender isso nos convoca à compreensão de que somos estranhos em e para nós mesmos (KRISTEVA, 1988). Como afirma Lacan (1966 [1998, p. 96-103], só nos vemos no e pelo espelho do olhar do outro, outro que internalizamos e que nos constitui. Somos, inevitavelmente, estrangeiros dentro do que chamamos nossa casa, nossa morada, nossa língua, nosso país; casa, morada, língua, país que não se deixam propriamente apropriar, que não são propriedade de ninguém (DERRIDA, 1996), a não ser pelas regras políticas e sociais que o ser humano inventa para (de)marcar fronteiras, fixar o instável, marcar o seu poder, submetendo outros à sua arbitrariedade, à sua lei.

Segundo fio. O sofrimento, acompanhado pelo gozo, ou pela dor, que traz prazer, o amor, a admiração pelo outro, pelo país do outro, pelo que o outro pode proporcionar, e ao mesmo tempo o ódio, por conta do sofrimento que o outro provoca no sujeito, faz emergir, nos relatos, a recorrência de oposições do tipo: o português é acolhedor / agressivo, educado-respeitoso / grosseiro-amargopessimista, em que a preferência por um dos polos depende das experiências pessoais, da relação que cada um estabelece $(\mathrm{u})$ com o outro, que, ao mesmo tempo, o(a) constitui e que ele(a) rejeita ou acolhe, que ele(a) estranha, naquilo que lhe parece (parecia?) mais familiar ("pensei que era diferente"; "é daqui MESMO que a gente tem as heranças"). Trata-se sempre de estranhamentos provocados pela falta do que ficou para trás, mas que parece estar sempre à frente, do que precisa ser esquecido, mas que está sempre na lembrança daqueles que imigraram. Nos demais, de passagem, há, também, o estranhamento, mas abrandado pelo sabor do retorno (cf. Fabiana), ou o deslumbramento que acompanha um efeito de estranhamento positivo, um amor em sua primeira fase, como no caso de Janete, impulsionando-a a querer ficar. 
Assim, é possível vislumbrar, quatro tipos de discurso que emergem dos dizeres dos participantes da pesquisa, discursos esses que têm a ver com a atitude de cada um perante o estranho, atitude que, por sua vez, constitui uma reação às representações de si e do outro, que urdiam o seu imaginário, antes de sua partida, rumo a uma "nova" vida: discurso de resistência ao outro (caso de Jussara), discurso de deslumbramento (caso de Janete), discurso de resignação e, portanto, de adaptação (caso de Geraldo) e, finalmente, embora ele atravesse o dizer de todos, o discurso do estranhamento (mais especificamente, no caso de Fabiana).

Cada um desses discursos, como é possível observar, nos poucos recortes aqui trazidos, estão atravessados por estereótipos, construídos por um já-dito, que, por ser reiterado ao longo dos anos, seja através de piadas ou de apreciaçóes subjetivas, se congela e se fixa, no imaginário do sujeito, como portador de verdades inquestionáveis. Esses estereótipos, sempre generalizantes, dificultam ou facilitam o contato com o outro, dependendo das experiências que os reforçam ou enfraquecem, possibilitando, inclusive, uma forte mudança no modo de se ver e (vi)ver o outro. Esse já-dito tanto diz respeito ao português quanto ao brasileiro: o português não é inteligente, é bruto e maleducado; o brasileiro é inteligente, simpático, educado, receptivo...

Terceiro fio. A situação em que se encontram os enunciadores (imigrantes ou simples passantes) modifica as reações diante das diferenças, diante do estrangeiro, que faz emergir, no sujeito, pontos de identificação, despertando marcas inconscientes e, por isso mesmo, indeléveis. A experiência do estranho, do estrangeiro, dentro ou fora de fronteiras geográficas, contribui para a transformação de uma identidade que não é nunca a mesma (Idem), mas que, enquanto vivos formos, sofrerá (ou gozará?) dessa transformação vidamorte-vida: morremos a cada instante para (vi)vermos, a cada experiência, o que resta do que éramos e o que somos e vemos.

Finalmente, é importante assinalar a pertinência da pesquisa, cujos resultados parciais acabamos de apresentar, pelas reflexōes que suscita sobre nossa própria identidade (quem somos?), sobre nossa língua-cultura (materna e / ou estrangeira? familiar e estranha, ao mesmo tempo). Refletir sobre essas questôes permite compreender melhor a si mesmo e ao outro, ao outro em si, que parece fora de si, externo a si, estrangeiro, de outro país ou dentro do país, de outra língua ou da mesma língua, de outro grupo social ou do mesmo grupo.

Kristeva (1988) parece sintetizar, do ponto de vista psicanalítico, o que tencionamos flagrar neste texto. Embora se coloque preferencialmente do lado 
daquele que hospeda (ou hostipeda?), Kristeva nos coloca diante de nós mesmos, tão estrangeiros quanto os (i)migrantes, estranhos que somos para e em nós mesmos:

Estrangeiro: raiva estrangulada no fundo de minha garganta, anjo negro turvando a transparência, traço opaco, insondável. Símbolo do ódio e do outro, o estrangeiro não é nem a vítima romântica de nossa preguiça habitual, nem o intruso responsável por todos os males da cidade. Nem a revelação a caminho, nem o adversário imediato a ser eliminado para pacificar o grupo. Estranhamente, o estrangeiro habita em nós: ele é a face oculta da nossa identidade, o espaço que arruína a nossa morada, o tempo em que caem no abismo o entendimento e a simpatia. Por reconhecê-lo em nós, poupamo-nos de detestá-lo em si mesmo. Sintoma que torna o "nós" precisamente problemático, talvez impossível, o estrangeiro começa quando surge a consciência da minha diferença e termina quando nos reconhecemos todos estrangeiros, rebeldes aos vínculos e às comunidades" (KRISTEVA, 1988, p. 9).

\section{Referências}

ALVES, Ieda M.; DESMET, Izabel. Neologia terminológica e variação geolectal (português europeu, português brasileiro e francês hexagonal): um projecto de cooperação. Disponível em: <http://www.realiter.net/spip.php?article211>. Acesso em: 9 mar. 2009.

AUTHIER-REVUZ, Jacqueline. Palavras Incertas - as não-coincidências do dizer. Campinas: Editora da Unicamp, 1998.

BAGNO, Marcos. Preconceito linguístico: o que é, como se faz. São Paulo: Loyola, 2005. BARTHES, Roland. (1977). Fragmentos de um discurso amoroso. Trad. H. dos Santos. Rio de Janeiro: Francisco Alves, 1990.

CALLIGARIS, Contardo. Hello, Brasil!' Notas de um psicanalista europeu viajando ao Brasil. São Paulo: Escuta, 1991.

CAMPOS, Maria Nilza; ARAGÃO, Regina Orth de. Riso e poder na transferência. Estados Gerais da Psicanálise. Disponível em: <http://www.estadosgerais.org/ atividades_atuais/riso_e_poder.shtml>. Acesso em: 9 mar. 2009.

9 Tradução minha. 
CORACINI, Maria José. Identidade e $O$ monolingüismo do outro. In:

A celebração do outro: arquivo, memória e identidade - línguas (materna e estrangeira), plurilinguismo e tradução). Campinas: Mercado de Letras, 2006. p.45-55.

CORACINI, Maria José (Org.). Identidade e discurso. Campinas / Chapecó: Editora da Unicamp / Argos, 2003.

DERRIDA, Jacques (1972a). A farmácia de Platão. Trad. Rogério da Costa. São Paulo: Iluminuras, 1991.

DERRIDA, Jacques. Positions. Paris: Editions de Minuit, 1972b.

DERRIDA, Jacques. Le monolinguisme de l'autre. Paris: Galilée, 1996.

DERRIDA, Jacques. De l'hospitalité. Paris: Calmann-Lévy, 1997.

FAULTSTICH, Enilde. Variações Terminológicas: princípios lingüísticos de análise e método de recolha, Realiter, 2009. Disponível em: <http:// www.realiter.net/spip.php?article265>. Acesso em: 9 mar. 2009.

FOUCAULT, Michel (1971). A ordem do discurso. Trad. Laura Fraga de Almeida Sampaio. Rio de Janeiro: Ediçôes Loyola, 1996.

FREUD, Sigmund (1919). O 'Estranho'. Edição Standard Brasileira das Obras Psicológicas Completas de Sigmund Freud, vol. XVII (1917-19). Trad. Jayme Salomão. Rio de Janeiro: Imago, 1976.

FREUD, Sigmund. (1930) O mal-estar na civilização. Trad. José Octavio de Aguiar Abreu. Rio de Janeiro: Imago, 1997.

GÄRTNER, E. (Ed.). Pesquisas linguísticas em Portugal e no Brasil. Frankfurt am Main: Vervuert; Madrid: Iberoamericana, 1997.

JON-AND, Anna. Estudo comparativo de concordância nominal e verbal em quatro variedades do português falado. Universidade de Estocolmo, [s.d.]. Disponível em: $<w w w . h u m . u v a . n l / t e m p l a t e / d o w n l o a d A s s e t . c f m ?$ objectid $=9$ E8060CE-727B-4848B31844FC9F0491A2>. Acesso em: 9 mar. 2009.

KRISTEVA, Julia. Etrangers à nous mêmes. Paris: Gallimard, 1988.

LACAN, Jacques (1966). O estádio do espelho como formador da função do eu. In: LACAN, J. Escritos. Trad. Vera Ribeiro. Rio de Janeiro: Jorge Zahar Editor, 1998. p. 96-103.

LACAN, Jacques (1975). Livro 20 (Mais, ainda). Trad. M. D. Magno. Rio de Janeiro: Jorge Zahar, 1985.

LUFT, Celso Pedro. Lingua e liberdade: por uma nova concepção da língua materna. 6. ed. São Paulo: Ática, 1998.

MILNER, Jean-Claude. L'amour de la langue. Paris: Editions du Seuil, 1978. 
PÊCHEUX, Michel; FUCHS, Catherine (1975). A propósito de uma análise automática do discurso: atualização e perspectivas. In: GADET, F.; HAK, T. (Org.). Por uma análise automática do discurso: uma introdução à obra de Michel Pêcheux. Trad. Bethânia Mariani et alii. Campinas: Editora da Unicamp, 1997. RICARDO-BORTONI, Stella Maris. Educação em lingua materna: a sociolingüística na sala de aula. São Paulo: Parábola, 2004.

Recebido em abril de 2009. Aprovado em julho de 2009 